\title{
Study of Biochemistry and Analytical of Metformin as a Suggested Pro-drug for Phosphoamide
}

\author{
*Rosal O. Mohammed \\ Firas Sh. Abdul-Razzaq \\ Department of Chemistry / College of Science/ University of Tikrit \\ *E-mail:ROSAL osama1234@gmail.com firasshawki@yahoo.com
}

(Received 15/10/2019 ; Accepted 26/11/2019)

DOI: $\underline{10.33899 / \text { rjs.2020.164474 }}$

\begin{abstract}
The aim of this study is to prepare a new phosphoamide pro-drug derived from metformin to minimize the side effect and study the effect of this derivative In vivo. The prepared compound was diagnosed by (Fourier Transform Infrared Radiology FTIR, Nuclear magnetic resonance of the proton ${ }^{1} \mathrm{H}-\mathrm{NMR}$, Mass spectroscopy). The effect of the prepared derivative was studied on rabbits، Forty Local rabbits By weights (1000-1800) g and ages (6-8) months were divided randomly into four groups. The first group (G1) consisting of 10 rabbit is a healthy control group that has not been given any substance. The second group (G2) consisted of 10 rabbits which were injected with alloxane $150 \mathrm{mg} / \mathrm{kg} \mathrm{B} . \mathrm{W}$ intraperitoneally (positive control).

The third group (G3) consists of 10 rabbits given $2 \mathrm{ml}$ of metformin at a concentration $0.0485 \mathrm{M}$ orally by agavage tube. The fourth group (G4) consists of 10 rabbits given $2 \mathrm{ml}$ of derivative at a concentration $0.0623 \mathrm{M}$ orally by agavage tube. Blood samples were withdrawn Method stab the 24hours heart after giving the last dose, which lasted for four days, which is the withdrawal on the fifth day and the serum was separated.

The results of the statistical analysis of the effect of the compound showed a significant decrease in the activity of aspartate aminotransferase compared with the positive control, and a significant decrease in the concentration of each of glucose, insulin as a result of the compound studied compared with the positive control, and no significant differences in the concentration of each of hormone $\mathrm{C}$ - peptide, urea, creatinine and the activity each of dipeptidyl peptidase-4, basal phosphatase, alanine aminotransferase as a result of the effect compared with positive control. There were no significant differences of the effect of the compound in the concentrations of glucose, insulin, hormone $\mathrm{C}^{-}$peptide, urea and creatinine, and the efficacy of the enzyme transporter aminotransferase and dipeptidyl betetidase -4 and aminotransferase compared with the control group (negative control) except the basal phosphatase enzyme was observed a significant increase compared to negative control.
\end{abstract}

Keywords : Diabetes Mellitus, Metformin, Phosphorus amid, Biochemical variables

\section{INTRODUCTION}

Diabetes mellitus (DM) is an increasingly common, potentially devastating, expensive, treatable, but incurable lifelong disease. The world health organizations (WHO) estimate that more than 220 million people worldwide have diabetes and this number is likely to be more than double by 2030. DM is associated with a number of chronic complications including nephropathy, neuropathy, retinopathy, and cardiovascular disorders. Many hypoglycemic agents, such as the biguanides and sulfonylureas, are used alone or together with insulin to treat this disease, however 
these medications can cause serious side effects, motivating a search for safer, more efficacious agents to control diabetes (Kamal et al., 2012).

The use of treatment for diabetics is necessary and essential from the first moment of the discovery of the disease because it aims to control the development of the disease and therefore no complications or the emergence of symptoms resulting from these complications are treatment either diet or exercise or use medicines (Manonmani and Manimekalai, 2018), and the patient often need to drug therapy when the blood sugar level is high despite diet and exercise and the general treatment is through: 1- Insulin hormone therapy 2- treatment with oral antihypertensive drugs Sugar: There are ten classes of oral medicines that can be used alone or with other oral medications, it may be used with insulin, such as biguanids compound (metformin). (Patakfalvi et al., 2019; Shantaram et al., 2014).

\section{Metformin}

It is a compound of biguanids which is a white crystals easily soluble in water and relatively dissolved in methanol and insoluble in acetone, ether and chloroform (Dujic et al., 2016) which works to reduce the liver production of diabetes used to treat type II diabetes and is usually considered a first-line treatment. Inhibiting intestinal glucose uptake and improving peripheral and hepatic insulin sensitivity but, also to reduce hepatic glucose production and promote the use of peripheral glucose (Davies et al., 2013), although the exact mechanism of action remains uncertain but, like other biguanides, does not stimulate insulin secretion (Zhou et al., 2016). Metformin suffers from slow bioavailability variable and causes non-infectious harm at effective doses (0.5-2 $\mathrm{ml} /$ day) such as abdominal pain, nausea, vomiting, diarrhea, loss of appetite, and mineral taste, for about 30\% of patients (Neha et al., 2013), but has effects Positive for hypertensive patients, vascular function and fibrous activity, and especially benefits for overweight patients especially in obese or hyperlipidemic patients (Griffin et al.,2017).

\section{Prodrug}

They are non effective (drug-inactive) therapeutic compounds that become metabolically active and are therefore different from soft drugs that are effective in their own right but become metabolically inactive (Karaman et al., 2013). The accompanying drug is characterized by its high molecular weight and high efficacy, so that medicines compete to bind to the active site of enzymes and thus the composition and active sites of enzymes play an important role in the work of concomitant drug(Huttunen and Rautio, 2011). The associated drugs have benefits that can be summarized, the most important in the following: (improve the patient's condition reduce pain or injury and absorption and biological proliferation and cellular metabolism) (Duggal et al., 2012).

\section{Prodrugs Classification}

Firstly carrier linked prodrug: This group includes the association of a drug carrier group for the purpose of improving the properties and efficacy of the drug with an enzymatic mechanism within the body where the active drug is released depending on the nature of the pregnant woman(Halen et al., 2009).

Second the accompanying drugs bio-split: This group is compound that contain specific efficacy within the structure of the drug, where it is ineffective and appears effective after entering metabolic pathways within the body of the organism (Kafarski et al., 2015).

\section{Organic Part}

\section{MATERIALS AND METHODS}

\section{Preparation of Metformin Derivative}

In a round bottom $(3.87 \mathrm{gm}, 0.023 \mathrm{~mole})$ of metformin was dissolved in $(30 \mathrm{ml})$ of a dimethyl sulfoxide (DMSO) and then added to the solution $(4 \mathrm{ml})$ of triethyl amine $\left(\mathrm{Et}_{3} \mathrm{~N}\right)$ and dropwise of 
$\left(0.9 \mathrm{ml}, 0.007\right.$ mole) of phosphoryl chloride $\mathrm{POCl}_{3}$ with stirring in an ice bath, The reaction continues for a whole day where a light brown precipitate is formed. Filtrate the mixture to get rid of the precipitate, extract by $(50 \mathrm{ml})$ of distilled water and $(50 \mathrm{ml})$ chloroform, evaporates the organic layer to obtain a brown precipitate and then purified by column chromatography to obtain the final product. The compound was characterized by a (Thin layer chromatography TLC, FTIR, ${ }^{1}$ H-NMR and Mass spectroscopy) to confirm the final composition of the resulting compound (AL-khalidy, 2014).

\section{Biochemistry Part}

Fourth adult males of local rabbits obtained from local markets, ages (6-8) months, and weights (1000-1800)g were used in this study. It was left for two weeks to adapt to new environmental conditions. The experimental animals were divided randomly into four groups, each group of 10 animals, and were treated (10) days after the onset of diabetes as follows:

(G1): The control group were given normal drinking water and no substance was given.

(G2): group of diabetic rabbits were injected with alloxane $150 \mathrm{mg} / \mathrm{kg} \mathrm{B.W}$ intraperitonealy (positive control).

(G3): group of diabetic rabbits given $2 \mathrm{ml}$ of metformin per rabbit at concentration $0.0485 \mathrm{M}$ orally by agavage tube.

(G4): group of diabetic rabbits given $2 \mathrm{ml}$ of the prepared compound per rabbit concentration $0.0623 \mathrm{M}$ orally by agavage tube.

At the end of the treatment which lasted for four days, the blood sample was withdrawn on the fifth day from each rabbit and the serum was separated to study Biochemical variables and enzymatic.

\section{Estimation of Biochemical Variables}

The concentration of hormone C-peptide, dipeptidyl peptidase-4 was determined by Elisa Technology according to the Bioassay Technology Laboratory from (China) and insulin hormone serum was determined by Elisa Technology according to the Elabscience from (USA). The concentration of glucose, creatinine, urea and the activity of the alanine aminotransferase, aspartite aminotransferase and alkaline phosphatase were estimated using a Special analysis by optical spectroscopy technique from Linear (Spain).

\section{Statistical Analysis}

The purely results were analyzed using and determined the differences between groups using the one-way analysis of Anova Duncan test (Duncan,1955).

\section{Organic Part:}

\section{RESULTS AND DISCUSSION}

The metformin phosphate derivative was prepared from the interaction of three molecules of metformin with one molecule of inorganic phosphate. The completing of the reaction confirmed by (TLC) chloroform and dietheyether (1:4), Reatardation factor $\mathrm{R}_{\mathrm{f}}$ for the associated drug (0.431) As the following equation:<smiles>CN(C)C(=N)NC(=N)NP(=O)(NC(=N)NC(=N)NC(=N)N(C)C(=N)NC(=N)N(C)C(=N)NC(=N)N(C)C)NC(=N)N(C)C</smiles>

The chemical structure of the prepared compound was confirmed using spectral methods $\left({ }^{1} \mathrm{H}-\right.$ NMR, FTIR, Mass spectroscopy) and as shown in the following forms:

Where the FTIR spectrum of the compound prepared is noted in Fig. (1): 


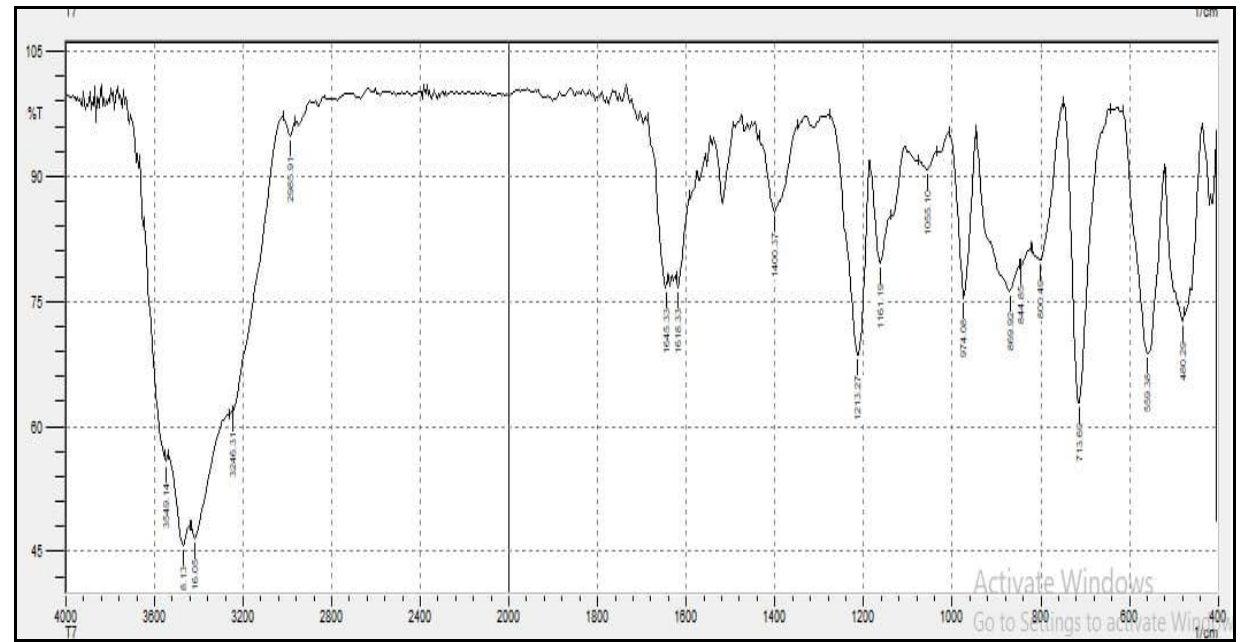

Fig. 1 : Shows the FTIR spectrum of the prepared compound

\begin{tabular}{|l|l|}
\hline \multicolumn{1}{|c|}{ Absorption valus } & \multicolumn{1}{c|}{ The group } \\
\hline 1-abeam in the area at $3416-3466 \mathrm{~cm}^{-1}$ & stretching NH for linked metformin \\
\hline 2- a sharp beam in the area at $2983 \mathrm{~cm}^{-1}$ & (C- $\mathrm{H}$ ) Aliphatic group \\
\hline 3-a sharp beam in the area at $1400 \mathrm{~cm}^{-1}$ & (C-N) group \\
\hline 4-a strong sharp beam in the area at $1213 \mathrm{~cm}^{-1}$ & p $=$ o group \\
\hline 5-a strong sharp beam in the area at $713 \mathrm{~cm}^{-1}$ & P-N group \\
\hline
\end{tabular}

The spectrum of the ${ }^{1} \mathrm{H}-\mathrm{NMR}$ was studied as shown in Fig. (2) using DMSO as a solvent. It was measured in units (ppm).

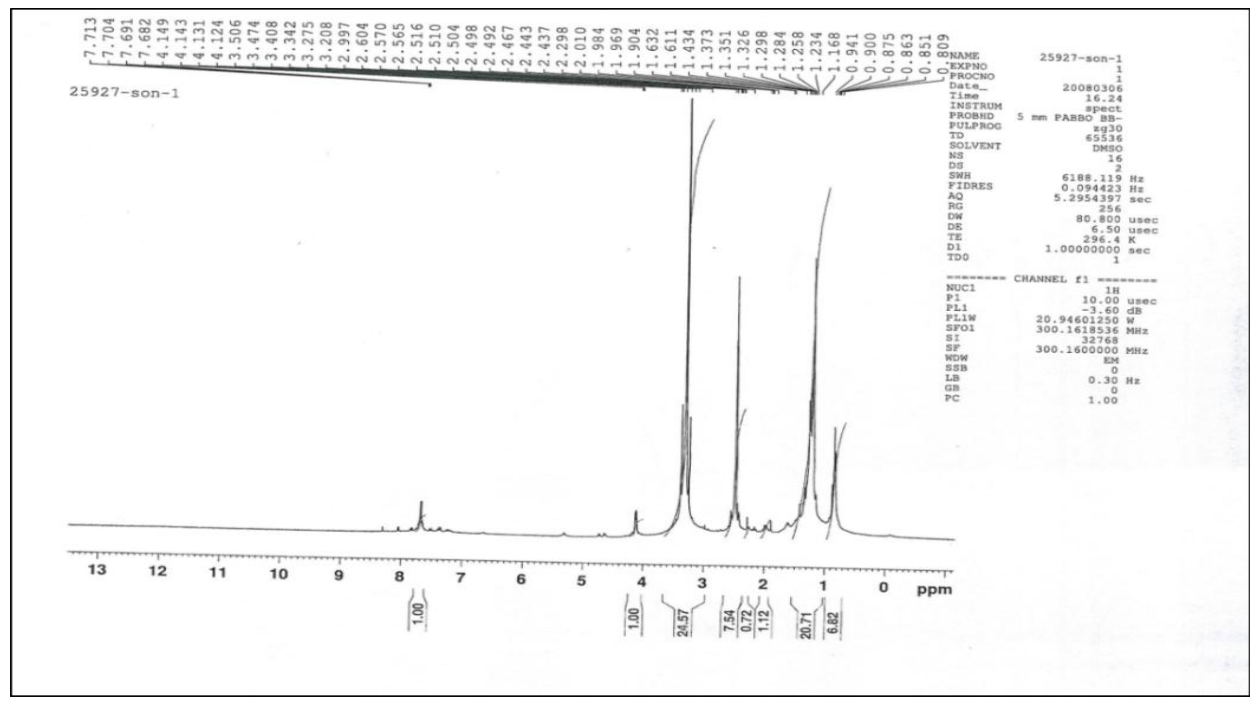

Fig. 2: Shows the H1-NMR spectrum of the prepared compound

\begin{tabular}{|l|l|}
\hline \multicolumn{1}{|c|}{ Absorption valus } & \multicolumn{1}{|c|}{ The group } \\
\hline 1- two signals in the region( 2.2-2.35) $\mathrm{ppm}$ & the protons $(\mathrm{NH})$ of metformin \\
\hline 2- signal at (3.2-3.4) ppm & the protons of the $\mathrm{N}(\mathrm{CH} 3)_{2}$ group \\
\hline 3- A signal at (2.5) $\mathrm{ppm}$ & solvent DMSO \\
\hline
\end{tabular}

Also the mass spectrum of the prepared compound was studied as shown in Fig. (3). It is noted from the spectrum that the prepared compound was bombarded by the 70 ev voltage and this effort is more than required to ionize any organic molecule. 


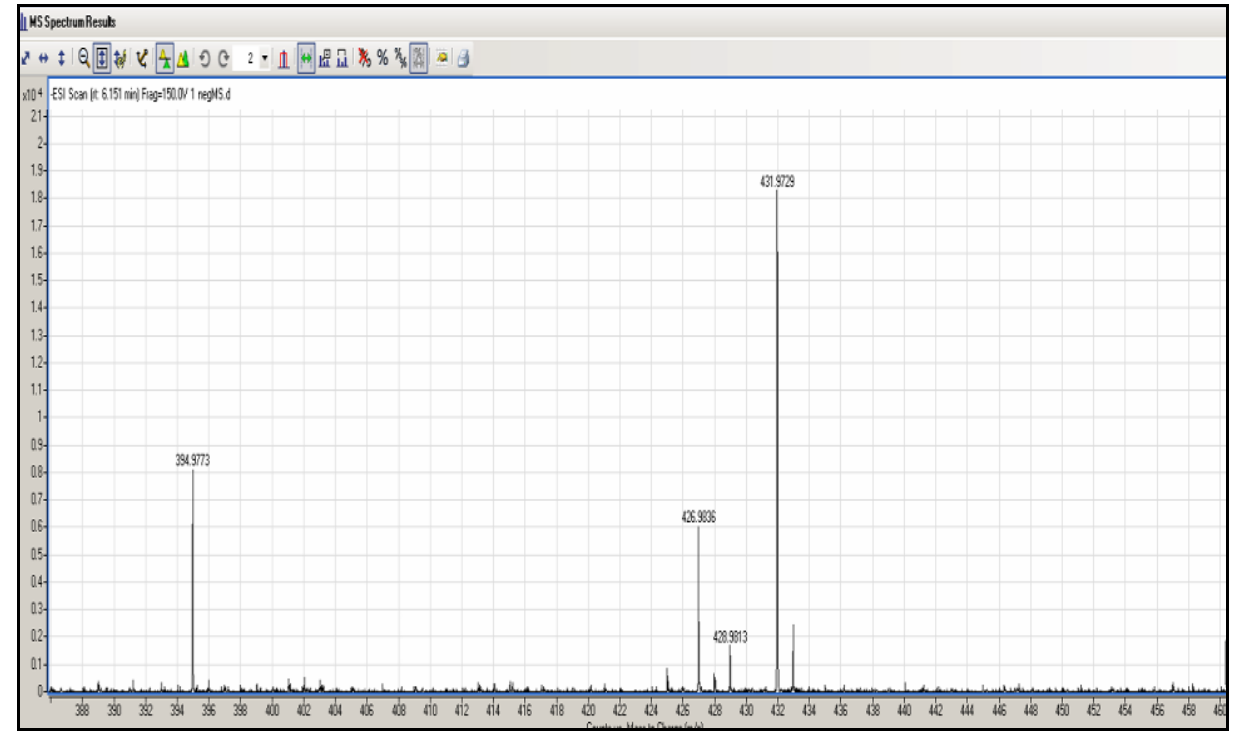

Fig. 3:The mass spectrum shows MASS SPECTRO

\begin{tabular}{|c|c|}
\hline Absorption valus & The group \\
\hline 1- height of the $431.25 \mathrm{~m} / \mathrm{z}$ & The $\left(\mathrm{M}^{+}\right)$molecular ions of the prepared compound \\
\hline $\begin{array}{l}\text { 2-The peaks observed in }(428.9813 \text { and } \\
426.9836) \mathrm{m} / \mathrm{z}\end{array}$ & $\begin{array}{l}\text { the fractionation of } 3 \text { atom and } 6 \text { atom hydrogen atoms } \\
\text { groups } \mathrm{N} \text {, which are small peaks for the loss of only a } \\
\text { hydrogen molecule }\end{array}$ \\
\hline ed $394.9773 \mathrm{~m} / \mathrm{z}$ & $\begin{array}{l}\text { indicates that the ion is more stable than the previous peaks } \\
\text { due to the fragmentation or loss of the hydrogenated group } N \\
\text { (CH3) } 2 \text { of the prepared compound. }\end{array}$ \\
\hline
\end{tabular}

\section{Biochemical variables}

\section{Comparison of glucose (Clu) and insulin (INS) concentrations}

The effect of the synthesized compound was measured on the glucose concentration (GLU). There was a significant difference between G1, G3, G4, with G2 and the levels of them were $(120.20 \pm 7.20)(183.30 \pm 68.7((115.40 \pm 25.49)(130.55 \pm 40.92) \mathrm{mg} / \mathrm{dl}$ for $\mathrm{G} 1, \mathrm{G} 2, \mathrm{G} 3$ and G4 respectively Fig. (4). It was noted that the level of glucose in the positive control group (alloxane treatment) G2 is significantly higher compared to the control group G1 because alloxane is characterized by its high toxicity that cause destruction of $\beta$ pancreatic cells, inhibits the secretion of insulin, responsible for the entry of glucose into the cells (Ahmed et al., 2015) or because of an imbalance in the receptors of cells responsible for the entry of glucose within the cells due to the oxidative stress caused by the free radicals represented by oxygen molecules unstable as the level of glucose in the farther rises (Bamidele et al., 2014). It was observed that the level of glucose in the G3 led to a decrease in its level compared with the group G2 and this corresponds to studies conducted on diabetic mice that dosed with metformin led to a decrease in the level of glucose as it stimulates the phosphorylation of Adenosine monophosphate protein kinase (AMPK) activity and activate chronic metabolism in skeletal muscle and inhibit the production of glucose in the liver cells (Okoh et al., 2015), reduce the absorption of glucose from the digestive system to the blood, and incompatible with the results of studies conducted for diabetic rats indicating that the level of blood glucose was high and decreased after four weeks (Musa et al., 2015) of the metformin treatment. The results showed no significant difference between the two groups G3 metformin treatment and G4 with the derivative prepared confirming the success of the desired goal for which the derivative attended where it worked as a drug to reduce the glucose Level in the blood. 


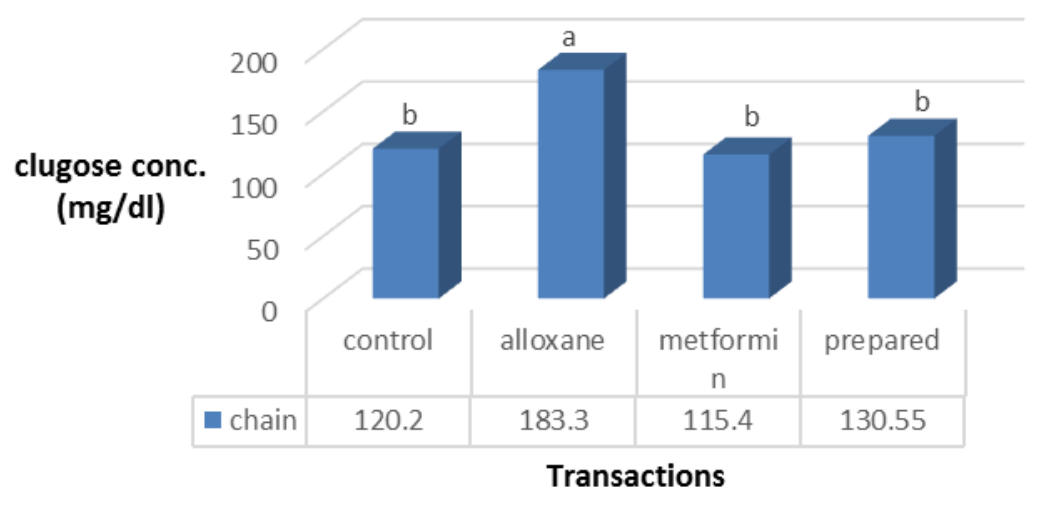

Fig. 4: Comparison of glucose concentration rates for the studied groups

The shapes are followed by different Letters indicate a significant difference at the level of probability ( $\mathrm{p} \leq 0.05$ ) and correct revers according Duncan test.

A significant difference was observed for insulin between the groups G1, G2, G3, and G4 and the concentration of them were $(16.95 \pm 6.21)(12.36 \pm 4.21)(5.39 \pm 3.56)(4.93 \pm 2.23) \mu \mathrm{u} / \mathrm{ml}$ Fig. (5).We note that the insulin concentration in the G2 diabetic animals was significantly lower compared to the G1 healthy control group because alloxane destroyed the existing beta cells in the pancreas, therefore decreases its secretion, instead of the sugar being transported to the cells that are needed for energy, sugar accumulates in the bloodstream that leads to diabetes (Etuk, 2010). In the treated group with metformin G3 the concentration insulin was significantly lower compared to the G2 group studies using metformin as a treatment for insulin resistance and improved sensitivity (increases peripheral absorption of glucose) used as a concomitant therapy to reduce insulin concentration and keep blood glucose concentration low in the blood (Lavine et al., 2010), while the G4 group had no significant difference compared to the G3 group which reduced its concentration. Insulin and reduced glucose level confirming the success of the desired goal of the derivative prepared for use as a drug for diabetics.

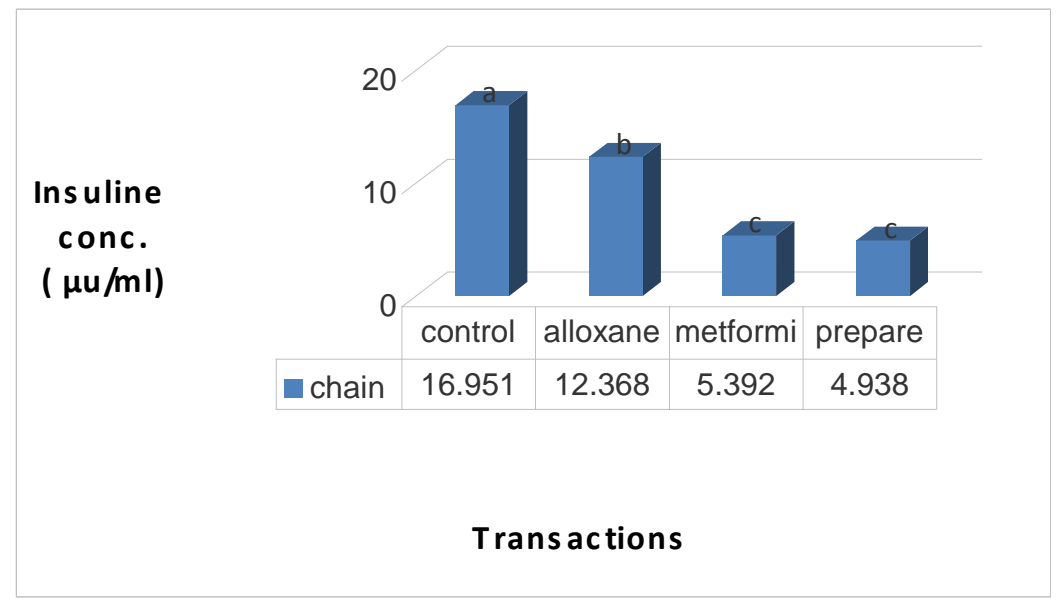

Fig. 5: Comparison of Insulin concentration rates for the studied groups

The shapes are followed by different Letters indicate a significant difference at the level of probability $(\mathrm{p} \leq 0.05)$ and correct revers according Duncan test. 


\section{Comparison of dipeptidyl peptidase -4(DPP-4) and c-peptide (CP)}

There was no significant difference in the effectiveness of the enzyme dipeptidyl peptidase 4 between G1, G2, G3, and G4 and the level of them were respectively (7.84 \pm 1.92$)(7.05 \pm 1.41)(6.56$ $\pm 2.25)(7.04 \pm 1.90) \mu \mathrm{u} / \mathrm{ml} \mathrm{Fig.} \mathrm{(6).} \mathrm{We} \mathrm{note} \mathrm{from} \mathrm{the} \mathrm{results} \mathrm{of} \mathrm{the} \mathrm{study} \mathrm{that} \mathrm{there} \mathrm{is} \mathrm{no} \mathrm{significant}$ differences in the effectiveness of the enzyme in the group infected with diabetes alloxane G2 compared to the control group G1 and this is inconsistent with the results of studies conducted on diabetic mice that confirmed high sugar works to destroy cells in the liver, which leads to decrease the effectiveness of the enzyme (Pala et al., 2012). In the treated group with metformin G3 there were no significant differences compared with the group dose alloxane G2 which is inconsistent with studies conducted on diabetic mice where there was a decrease in the concentration of the enzyme DPP-4 due to the fact that the drug metformin is an enzyme inhibitory drugs that reduce blood sugar (Fadini et al., 2012).In the G4 group there were no significant differences compared to the $\mathrm{G} 2$ group indicating that the prepared derivative does not affect the activity of the enzyme.

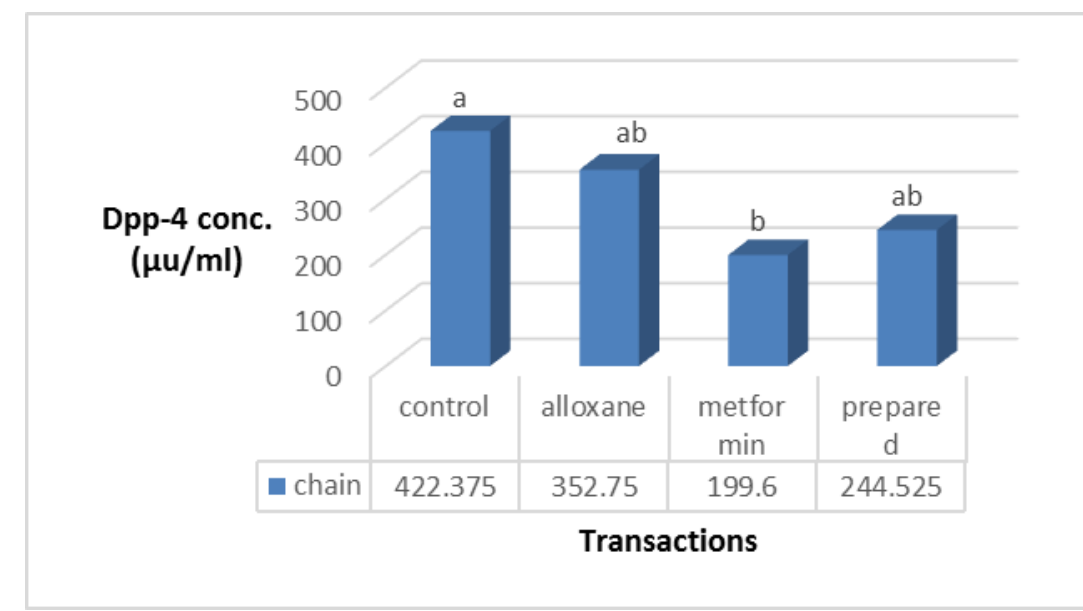

Fig. 6:Comparison of DPP-4 concentration rates for the studied groups

The shapes are followed by different Letters indicate a significant difference at the level of probability $(\mathrm{p} \leq 0.05)$ and correct revers according Duncan test.

A review of the numbers of the $\mathrm{C}$ - peptide variable showed significant difference was observed between the groups G1, G2, G3, and G4 and the levels them were (422.37 \pm 328.95) (352.75 \pm 172.60) $(199.60 \pm 76.57)(244.52 \pm 133.00) \mu \mathrm{u} / \mathrm{ml} \mathrm{Fig.} \mathrm{(7).} \mathrm{The} \mathrm{results} \mathrm{showed} \mathrm{that} \mathrm{there} \mathrm{was} \mathrm{no}$ significant difference in the concentration of C-peptide in the group alloxane G2 compared with the control group G1. This is inconsistent with a study that showed a decrease in C-peptide concentration due to the destruction of pancreatic $\beta$ cells that lead to diabetes (Ghorbani and Shafiee, 2015). The concentration of C-peptide decreased in the group G3 treated with metformin compared with the control group G1 where metformin increases the insulin sensitivity of cells and thus reduced blood sugar concentration (Akalin et al., 2018). The new companion does not affect the level of concentration. 


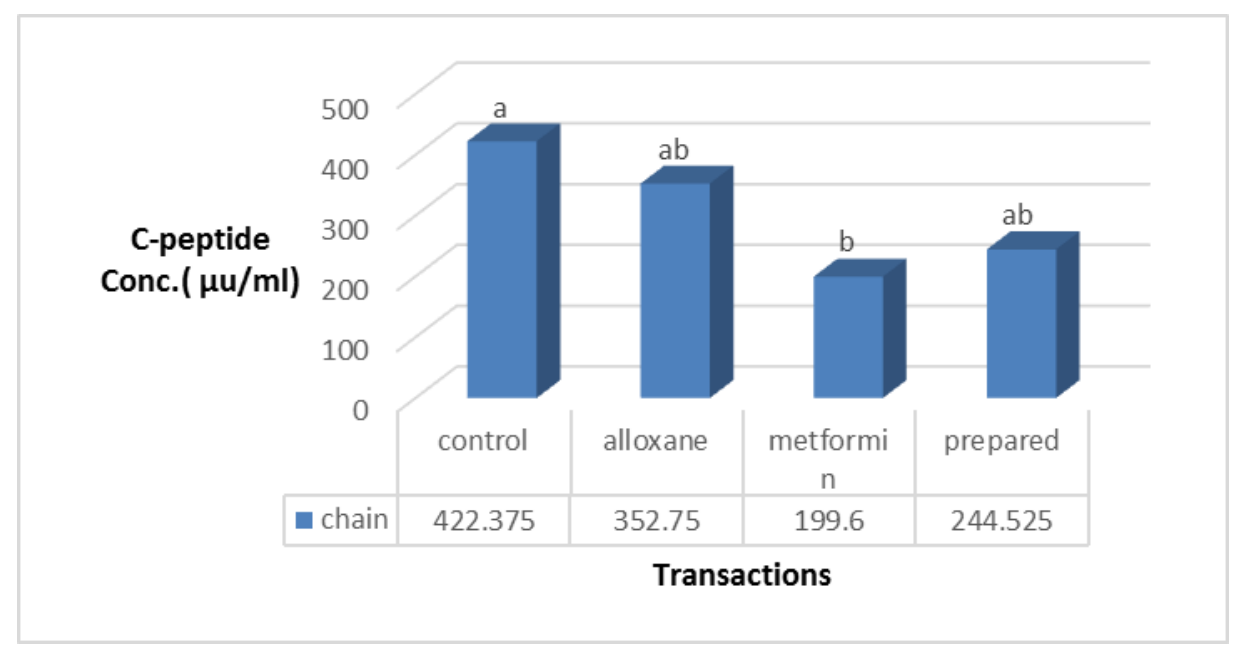

Fig. 7: Comparison of C-Peptide concentration rates for the studied groups

The shapes are followed by different Letters indicate a significant difference at the level of probability $(\mathrm{p} \leq 0.05)$ and correct revers according Duncan test.

\section{Comparison of Urea and Creatinine concentration}

Review for urea concentration observed no significant difference between the groups G1, G2, $\mathrm{G} 3$, and G4 and levels them were $(42.70 \pm 7.49)(54.40 \pm 25.50)(51.80 \pm 35.22)(33.37 \pm 10.08)$ $\mathrm{mg} / \mathrm{dl}$ Fig. (8). There are no significant differences between the four groups where they are convergent. No significant differences in the concentration of urea in the G2 diabetic animal compared to the control group G1, and incompatible with a study conducted that showed that high blood sugar leads to damage in the renal glomeruli kidneys that act as a filter to clean the blood therefor, any imbalance in the kidney leads to not dropping excess waste properly and increasing urea (Idonije et al.,2011).In the treated group with metformin G3 we note the absence of significant differences and this is consistent with studies conducted on diabetic mice as metformin does not affect on the healthy kidney and does not lead to disorders of kidney function, where the drug is thrown without change in its structure through glomerular renal clearance (Reed et al., 2000), and is not compatible with studies conducted where it showed the risk of accumulation of metformin in the case of renal insufficiency leads to increased formation of lactic acid (Lactic acid ) causes death in $40 \%$ of patients because it is naturally converted to glucose so that lactic acid is transported from the muscles to the liver in a cycle called the Cory cycle and is converted to glucose and to glycogen that is stored in the liver or muscles (Abbas et al., 2016). In the $\mathrm{G} 4$ group no significant differences were observed. The prepared compound showed no effect on urea concentration level.

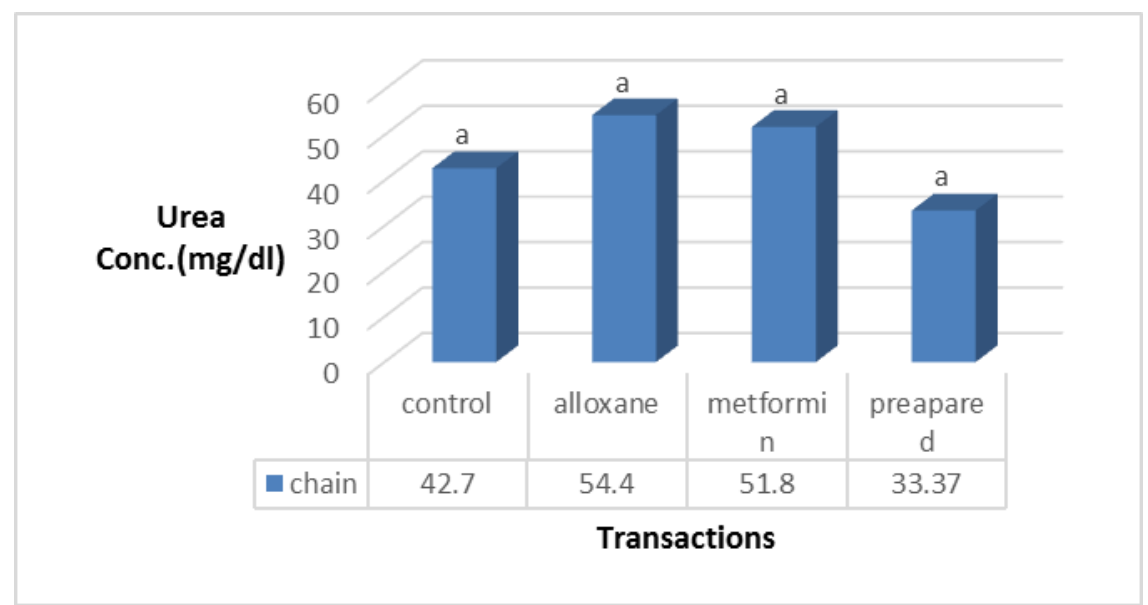

Fig. 8:Comparison of urea concentration rates for the studied groups 
The shapes are followed by different Letters indicate a significant difference at the level of probability $(\mathrm{p} \leq 0.05)$ and correct revers according Duncan test.

Review for creatinine concentration there was no observed significant difference between G1, G2, G3, and G4 and the levels of them were respectively $(1.12 \pm 0.39)(1.008 \pm 0.51)(1.55 \pm 1.65)$ $(0.65 \pm 0.91) \mathrm{mg} / \mathrm{dl}$ Fig. (9). There are no significant differences in creatinine concentration between the healthy G1 and G2 diabetic groups where the proportions are similar. These results are inconsistent with a study that showed that creatinine has to do with the size of the muscle mass in the body and since the skeletal muscle is the main tissue of insulin. Small skeletal muscle size means few effective insulin sites and thus increased insulin resistance and leads to diabetes (Pei et al., 2012). In group G3 treated with metformin no significant differences in creatinine concentration were observed and compatible with study to the healthy groups by giving them a single dose as an intravenous injection. Metformin is eliminated in the urine without any change and the liver has no effect on its metabolic processes (Henzler et al., 2007). In the derivative group G4 it was observed that creatinine was not affected as it remained concentrated.

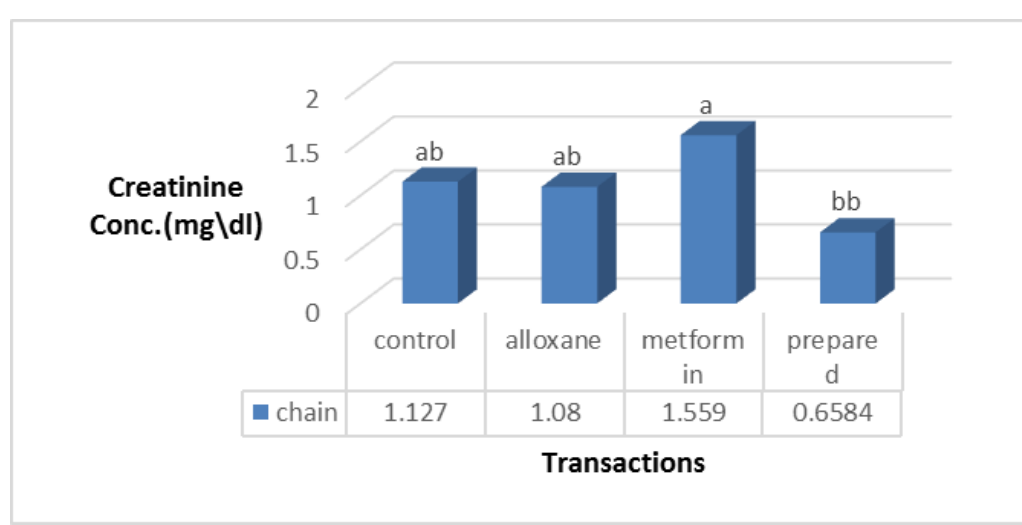

Fig. 9: Comparison of Creatinine concentration rates for the studied groups

The shapes are followed by different Letters indicate a significant difference at the level of probability $(\mathrm{p} \leq 0.05)$ and correct revers according Duncan test.

\section{Comparison of enzymes activity [Alkaline phosphatase (ALP), Aspartate aminotransferase (AST), Alanine aminotranseferase (ALT)]}

Review of the results of the enzyme activity alkaline phosphatase (ALP) showed a significant difference between G2, G3, G4 with G1 and the activity of this enzymes in the groups G1, G2, G3, G4 respectively: $(31.00 \pm 12.63)(61.20 \pm 13.83)(60.60 \pm 27.81)(60.40 \pm 23.23) \mathrm{U} / \mathrm{L}$ Fig. (10). The activity of the enzyme in the group with diabetes $\mathrm{G} 2$ increases compared to the control group G1 as in a study showed that the activity of ALP increases with increased blood glucose that this increase in the activity of ALP is usually due to many diseases such as liver disease or bile duct or the presence of stones in the gallbladder may indicate high ALP Bone diseases such as Osteopenia or Osteoporous also cause blood disorders to increase the activity of ALP in addition to certain cancers and high levels of glucose lead to liver damage (Guimarães et al., 2007). The increase in serum basal phosphatase activity in diabetes can be the result of an increased for energy during ALP activity instead of glycolysis and oxidation pathway phosphate-6-Glucose which causes the decomposition and damage of liver cells (Elhabashy et al., 2011) ALP is a widely used evidence for bone metabolism provides a good impression of the extent of new bone formation and osteoblast activity, and not compatible with the results of the study showed that there was no change in the effectiveness of the enzyme in the healthy control group compared to the group with diabetes (ISSA et al., 2011). In the G4 derivative group there was no change in the activity of the basal phosphatase enzyme. This indicates that there are few side effects of the prepared compound. 


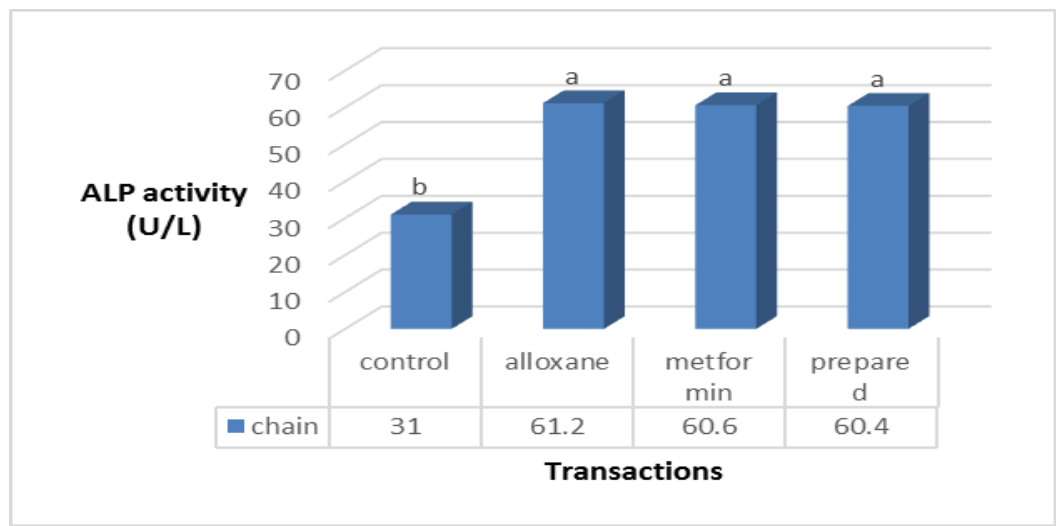

\section{Fig. 10: Comparison of ALP activity rates for the studied groups}

The shapes are followed by different Letters indicate a significant difference at the level of probability $(\mathrm{p} \leq 0.05)$ and correct revers according Duncan test.

Review of the results of enzyme activity aspartate aminotransferase (AST) was observed to have a significant difference between G1, G3, and G4 with G2 and the activity of aggregates G1, G2, G3, G4 (11.93 \pm 5.83$)(38.85 \pm 6.59)(15.60 \pm 8.40)(15.85 \pm 8.22) \mathrm{U} / \mathrm{L}$ respectively Fig. (11). The rate of enzyme activity in the G2 diabetic group was significantly higher compared to the control group G1mainly due to the breakdown of hepatocytes which is usually accompanied by high enzyme ratio. High enzyme activity in diabetic animals may be due to the metabolic imbalance caused by the development of diabetes leading to increased metabolism and enlargement of hepatocytes and stimulate the endoplasmic reticulum to produce a larger amount of enzyme commensurate with the size of Cells, hormonal disorders and impaired metabolism in diabetics are usually accompanied by enzyme activity (Aja et al., 2015). There were no significant differences in the activity of the enzyme group G4 compared with the group treated with metformin G3 which indicates that the compound prepared to repair the damage to the liver and the systems to release the enzyme extracellular similar to the work of metformin.

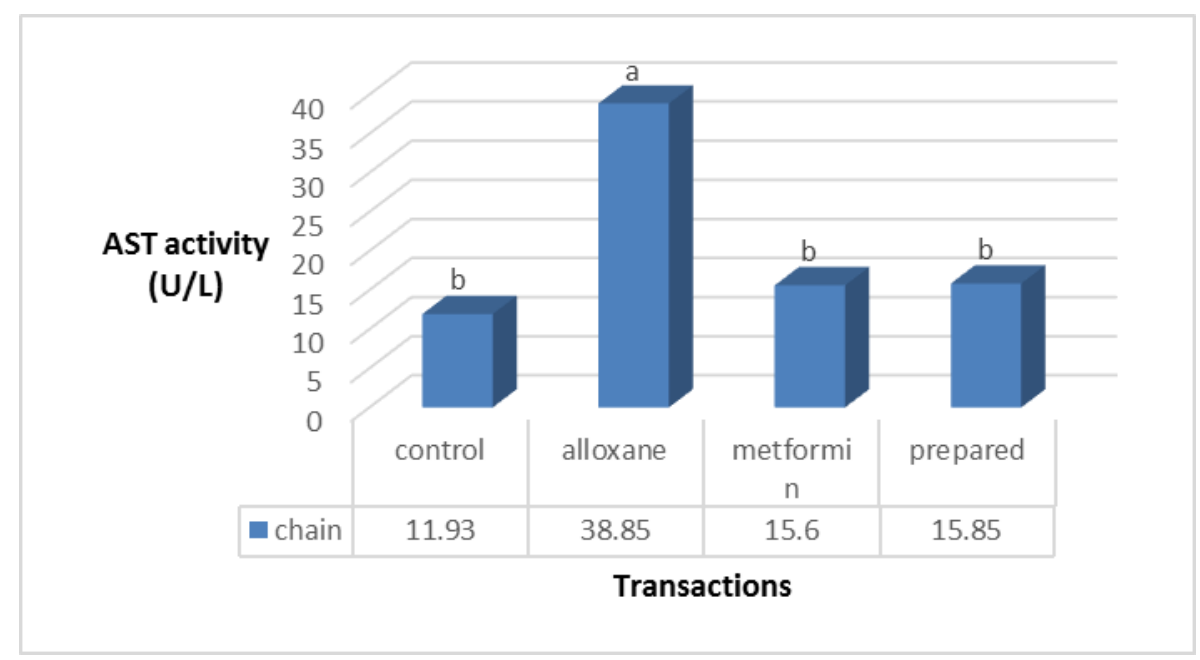

Fig. 11: Comparison of AST activity rates for the studied groups

The shapes are followed by different Letters indicate a significant difference at the level of probability $(\mathrm{p} \leq 0.05)$ and correct revers according Duncan test.

Results were reviewed for enzyme activity alanine aminotranseferase (ALT) No significant difference was observed between G1, G2, G3, G4 and the activity of them were (18.36 \pm 8.94$)$ (15.40 \pm 6.22$)(18.61 \pm 15.60)(17.24 \pm 8.94) \mathrm{U} / \mathrm{L}$ respectively Fig. (12). No significant differences 
were found in the G2 diabetic group (positive control) compared with the G1 control group these results are inconsistent with a study conducted in the liver where liver enzyme levels are higher in diabetics compared to healthy animals where aloxane increases the activity of Trassaminase enzymes in both liver and serum (Nishra et al., 2017). The results showed that the enzyme activity was not affected when treated with metformin and the new metformin-derived companion drug.

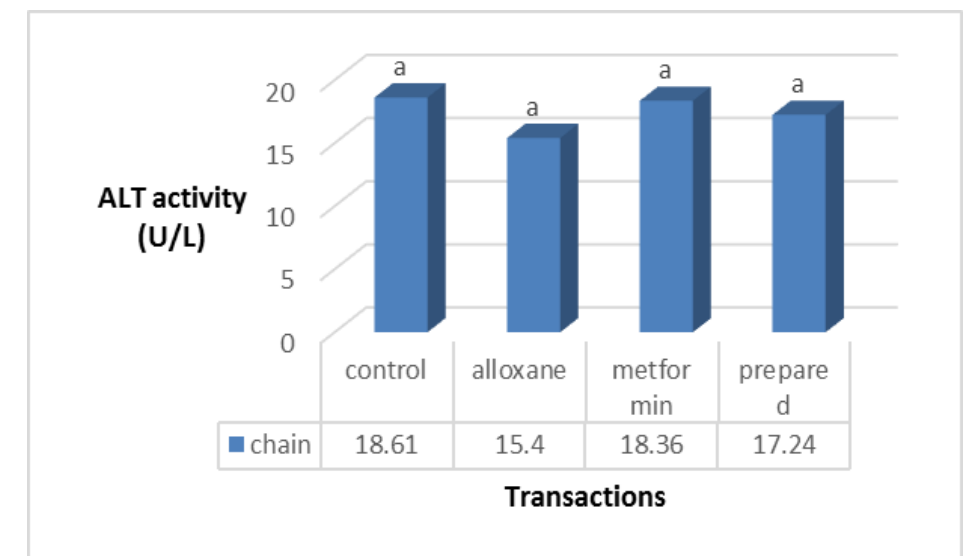

Fig. 12: Comparison of ALT activity rates for the studied groups

The shapes are followed by different Letters indicate a significant difference at the level of probability $(\mathrm{p} \leq 0.05)$ and correct revers according Duncan test.

\section{CONCLUSIONS}

The prepared derivative reduce the concentration of glucose ,insulin and activity of aspart aminotransferase (AST) compared with diabetic group. No significant difference in the concentration c-peptide, urea, creatinine, dipeptidyl peptidase-4, alkaline phosphatase (ALP) and alanine aminotransferase (ALT). The associated drug decomposes in the basal medium more slowly than in the acidic medium. The effectiveness of the compound prepared for use as a treatment for type 2 diabetes to reduce blood glucose level is higher than the effectiveness of the drug alone.

\section{REFERENCES}

Abbas, S.Y.; Basyouni, W.M.; El-Bayouki, K.A.M.; Abdel-Rahman, R.F. (2016). Synthesis and evaluation of 1-substituted-biguanide derivatives as anti-diabetic agents for type 2 diabetes insulin resistant. Drug Research, 66(07), 377-383.

Ahmed, A.A.; Fedail, J.S.; Musa, H.H.; Kamboh, A.A.; Sifaldin, A.Z.; Musa, T. H. (2015). Gum Arabic extracts protect against hepatic oxidative stress in alloxan induced diabetes in rats. Pathophysiology, 22(4), 189-194.

Aja, P.M.; Ani, O.G.; offor, U.O.; Orji, U.O.; Alum, E.U. (2015). Evolution of Anti -Diabetic effect and liver Enzymes activity of Ethanol Extract of Pterocarpus Santaalinoides in Alloxane induced Diabetic Albino Rats. Global Biotechno. and Biochem., 10(2), 77-83.

Akalin, S.; Aydin, H.; Balci, M. K.; Çömlekçi, A.; Dinççağ, N.; Erbaş, T.; Zeynep, O. Ş. A. R. (2018). Use of Biphasic Insulin Apart 30 in Type 2 Diabetes Treatment: expert panel recommendations. Turkish J. Endocrinol. and Metabolism., 22(3), 183.

AL-khalidy, B. (2014). Synthesis of some new phosphate paracetamol derivatives proposed as prodrug and study their effect on alkaline phosphatase which purified from serum of diabetic patient. Tikrit University, Iraq, 42-43. 
Bamidele, O.; Arokoyo, D.S., Akinnuga, A.M.; Oluwarole, A.O.(2014). Antidiabetic effect of aqueous extract of Basella alba leaves and metformin in alloxan- induced diabetic albino rats. African J. Biotechnol., 13(24), 2455-2458.

Davies, M.; Heller, S.; Sreenan, S.; Sapin, H.; Adetunji, O.; Tahbaz, A.; Vora, J. (2013). Onceweekly exenatide versus once-or twice-daily insulin detemir: randomized, open-label, clinical trial of efficacy and safety in patients with type 2 diabetes treated with metformin alone or in combination with sulfonylureas. Diabetes Care, 36(5),1368-1376.

Duggal, S., Rathore, P., Kanwar, K. (2012). Prodrug: novel approaches for anti- inflammatory actions of NSAID's. International J. Pharmacol. and Technol., 4(1), 1889- 1908.

Dujic, T.; Zhou, K.,; Tavendale, R.; Palmer, C.N.; Pearson, E.R. (2016). Effect of serotonin transporter 5-HTTLPR polymorphism on gastrointestinal intolerance to metformin: a GoDARTS study. Diabetes Care, 39(11), 1896-1901.

Duncan, D.B. (1955). Multiple range multiplet f. test . Biometrics., 11, 1-42.

Elhabashy, S.A.; Said, O.M.; Agaiby, M.H.; Abdelrazek, A.A.; Abdelhamid, S. (2011). Effect of physical exercise on bone density and remodeling in Egyptian type 1 diabetic osteopenic adolescents. Diabetol. and Metabolic Syndrome, 3(1), 25.

Etuk, E.U. (2010). Animals model for studding diabetes mellitus. Agriculture and Biological J. North America, 1(2), 130-134.

Fadini, G. P.; Albiero, M.; Menegazzo, L.; De Kreutzenberg, S.V.; Avogaro, A. (2012). The increased dipeptidyl peptidase-4 activity is not counteracted by optimized glucose Diabetes control in type 2 diabetes, but is lower in metformin-treated patients. Obesity and Metabolism, 14(6), 518-522.

Ghorbani, A.; Shafiee-Nick, R. (2015). Pathological consequences of c-peptide deficiency in insulin -dependent mellitus. World . J. Diabetes, 6,145-150.

Griffin, S. J.; Leaver, J. K.; Irving, G. J. (2017). Impact of metformin on cardiovascular disease: a metaanalysis of randomized trials among people with type 2 diabetes. Diabetologia, 60(9), 16201629.

Guimarães, L. H. S.; Júnior, A. B.; Jorge, J. A.; Terenzi, H. F.; Polizeli, M. L. T. M. (2007). Purification and biochemical characterization of a mycelial alkaline phosphatase without DNAase activity produced by Aspergillus caespitosus. Folia Microbiologica., 52(3), 231.

Halen, P.K.; Murumkar, P.R.; Giridhar, R.; Yadav, M.R. (2009). Prodrug designing of NSAID. Mini- Reviews in Med. Chem., 9(1), 124-139.

Henzler-Wildman, K.A.; Thai, V.; Lei, M.; Ott, M.; Wolf-Watz, M.; Fenn, T.; Hübner, C.G. (2007). Intrinsic motions along an enzymatic reaction trajectory. Nature, 450(7171), 838.

Huttunen, M.K.; Rautio, J. (2011). Prodrugs-an efficient way to breach delivery and targeting barriers. Current Topics in Med. Chem., 11(18), 2265-2287.

Idonije, B.O.; Festus, O.; Oluba, O.M. (2011). Plasma glucose, creatinine and urea levels in type 2 diabetic patients attending a Nigerian teaching hospital. Research J. Med. Sci., 5(1), 1-3.

ISSA, C.; Zantout, M.S.; Azar, S. T.(2011). Osteoporosis in men with diabetes mellitus. $J$. Osteoporosis., 651-867.

Kafarski, P.; Górniak, M.G.; Andrasiak, I. (2015). Kabachnik-Fields reaction under green conditions-A critical over-view. Current Green Chem., 2, 218-222.

Kamal, A.Kh.; Sarmad, R.K.; Ismail, S.K. (2012). Role of green tea extract in reducing pathological changes of induced diabetes mellitus in rats. Al-Rafidain J. Sci., 24(7)1-12.

Karaman, R.; Fattash, B.; Qtait, A. (2013). The future of prodrugs-design by quantum mechanics methods. Expert Opinion on Drug Delivery, 10(5), 713-729. 
Lavine, J.E.; Schwimmer, J.B.; Molleston, J.P.; Scheimann, A.O.; Murray, K.F.; Abrams, S.H.; Ünalp, A. (2010). Treatment of nonalcoholic fatty liver disease in children; TONIC trial design. Contemporary Clinical Trials, 31(1), 62-70.

Manonmani, M.; Manimekalai, K. (2018). A study of serum magnesium level in Type 2 Diabetes mellitus patients. J. Diabetes Mellitus, 8(02), 20.

Musa, H.H.; Ahmed, A.A.; Musa, T.H.; Fedail, J.S. (2015). Gum Arabic down-regulat PPAR- $\gamma$ and SCD mRNA expression in mice. Polish Annals of Medicine, 22(1), 11-17.

Neha. K.; Anupam, B.; Shweta, V.; Basant, S. (2013). Design, synthesis of guanidine derivatives and their antihyperglycemic evaluation. Der. Pharma. Chemica., 5(2), 59-66.

Nishra, N.; Mohammed, A.; Rizvi, S.I. (2017). Efficacy of Lepidium Sativum to act as an antidiabetic agent . Progress in Health Sci., 7(1), 44-53.

Okoh, M.P.; Nwose, C.; Nwachukwu, K.C. (2015). Comparative effects of Portulaca oleracea and Metformin in Diabetes Mellitus Rat induced with Alloxan.J. Pharmaceutical Chem. and Biolog. Sci., 3, 358-366.

Pala, L.; Pezzatini, A.; Dicembrini, I., Ciani, S.; Gelmini, S., Vannelli, B. G.; Rotella, C.M. (2012). Different modulation of dipeptidyl peptidase-4 activity between microvascular and macrovascular human endothelial cells. Acta Diabetologica,49 (1), 59-36.

Patakfalvi, L.; Brazeau, A.S.; Dasgupta, K. (2018). Physician experiences with sodium-glucose cotransporter (SGLT2) inhibitors, a new class of medications in type 2 diabetes, and adverse effects. Primary Health Care Research and Development, 20,1-6.

Pei, D., Ding, J., Duan, Z.; Li, M.; Feng, Y.; Li, C. (2012). Cloning and expression of a tomato glutathione S-transferase (GST) in Escherichia coli. African J. Biotechn. , 11(23), 6402-6408.

Reed, M.J.; Meszaros, K.; Entes, L.J.; Claypool, M.D.; Pinkett, J.G.; Gadbois, T.M.; Reaven, G.M. (2000). A new rat model of type 2 diabetes: the fat-fed, streptozotocin -treated rat. Metabolism-Clinical and Experimental, 49(11), 1390-1394.

Shantaram, M.; Anusha, M.S.; Chethana. (2014). Serum Adenosine Deaminase Activity in Type 2

Diabetes Mellitus. J. Pharmaceutical and Biomedical Sci., 246-248.

Zhou, B:, Wu, L.; Oshiro-Rapley, N.; Li, M.; Paulo, J.A.; Webster, C.M.; Gygi, S.P. (2016). An ancient, unified mechanism for metformin growth inhibition in C. Elegans and Cancer Cell, 167(7), 1705-1718.

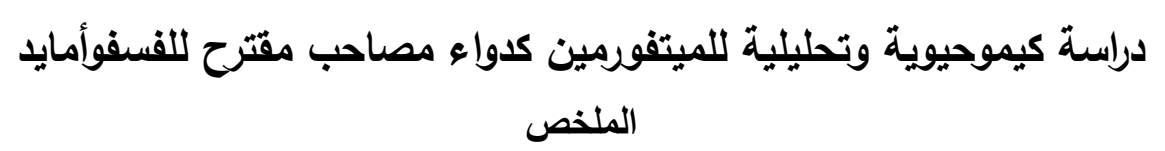

الهدف من هذه الدراسـة هو إعداد عقار جديد مؤلف من عقار الفسفوامايد مشتق من الميتفورمين لتقليل الآثار الجانبية

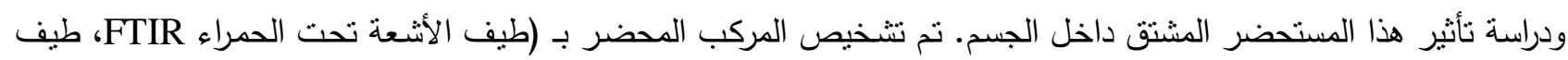

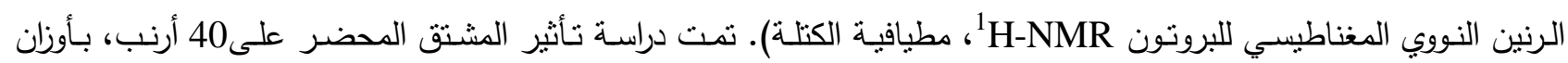

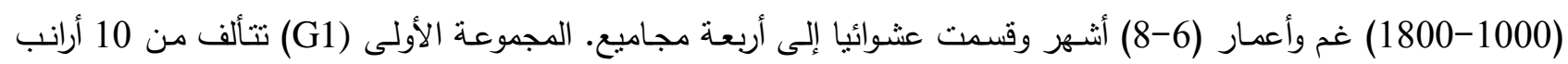

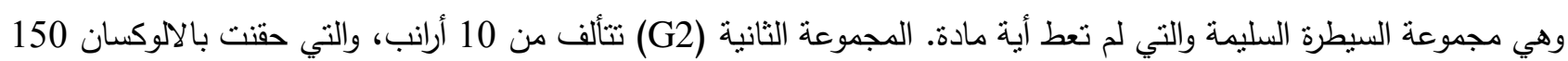
ملغم/ كغ داخل الغشاء البرينوني (السيطرة الموجبة). المجموعة الثالثة (G3) نتألف من 10 أرانب وأعطيت الميتفورمين 2 مل بتركيز 0.0485 مولاري فمويا بوساطة أنبوب التجريع الفموي. المجموعة الرابعة (G4) تتألف من 10 أرانب وأعطيت 2مل من المشتق بتركيز 0.0623 مولاري فمويا بوساطة 
أنبوب التجريع الفموي. وسحبت عينات الدم بطريقة طعنة القلب بعد إعطاء أخر جرعة ب24 ساعة والتي استمرت لمدة اربعة

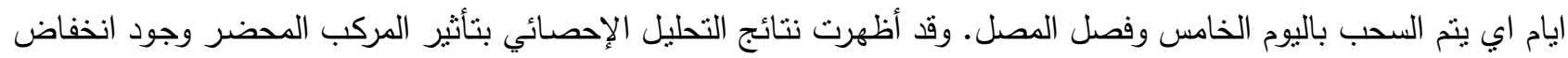
معنوي في فعاليـة كل من أنزيم ناقل امين الاسبارتيت مقارنة مسع السبطرة الموجبـة، ووجود انخفاض معنوي بتركيز كل من

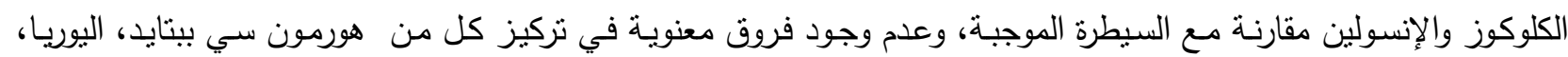
الكرياتتين، فعالية انزيم كل من ثنائي بييتدايل ببييتديز -4، الفوسفاتيز القاعدي، ناقل امين الالنين مقارنة مع السيطرة الموجبة. وعدم وجود فروف معنوية بتأثثر المركب المحضر في تراكيز كل من الكلوكوز، الانسولين، هورمون سي ببتايد، اليوريا، الكرياتتين وفعالية كل من انزيم ناقل امين اسبارتيت، ثنائي ببتدايل ببيتديز - ؛ وناقل امين الالنين مقارنـة مع مجموعـة السيطرة السليمة (السيطرة السالبة)، ماعدا فعالية انزيم الفوسفاتيز القاعدي لوحظ وجود ارتفاع معنوي مقارنة مع السيطرة السالبة. الكلمات الدالة: داءالسكر ، الميتفورمين، الفسفوراميد، المتغيرات الكيموحيوية. 